\title{
Quality Control and Re-use of Water in California
}

\author{
Adolphus Moskovitz*
}

The main outline of California's Water Problem is familiar to everyone attending this conference. Water in our state is maldistributed not only geographically and seasonally as compared to need, but also from year to year. As a consequence, for a long time we have been aware of the necessity of conserving our rainfall and snow-melt during the seasons and years when nature provides them and of transporting the water so accumulated from the areas where it is in surplus to the areas where it is needed and can be put to use. That is, we have long been quantity-conscious.

In recent years, however, we have begun to recognize that to make the most efficient use of our water resources, it is not enough merely to increase the quantity available. In our expanding, complex economy, the same water must be used many times and for many different purposes before it flows to the sea or evaporates. Drinking and domestic use, irrigation, maintenance of fish and wildlife, industrial use, recreational use, navigation, generation of hydroelectric power, disposal of sewage and industrial waste- these are some of the purposes for which the same water may have to be used, and more than once, as it flows from the mountains to the sea.

Most water uses need water of a certain minimum quality. On the other hand, most water uses tend to degrade quality of the water and thus affect its suitability for subsequent use. Hence, if multiple and successive uses of the same water are to be protected, the maintenance of water quality and prevention of water pollution become as vital as the development of sufficient water quantities. And the right to re-use water which has been used before becomes as important as the right to make the first use.

The purpose of this paper is to discuss the law of California governing these two related subjects-first, the control of water quality and water pollution and second, the acquisition of rights to re-use water which has been put to previous use.

\section{I}

\section{CONTROL OF WATER QUALITY AND WATER POLLUTION}

In 1949, the California legislature made a sweeping revision of state law relating to control of water quality and water pollution. Although nearly eight years have elapsed since the new statutes went into effect, there have been no court tests of any of them even on the trial court level. Therefore, the discussion which follows is based on the statutes themselves, with some

* Deputy Attorney General, State of California, Sacramento. 
assistance from opinions of the Attorney General construing them and from the practical application of the statutes by the agencies which administer them.

Prior to 1949, the major statewide responsibility for preventing both public health hazards and economic damage resulting from the discharge of wastes into the waters of the state was exercised by the State Department of Public Health. ${ }^{1}$ The law then in effect required a permit from the Department for any discharge of wastes and for the construction or operation of any waste treatment or disposal facilities. A permit was to be demed if the Department believed the discharge either would endanger the public health or cause a nuisance. The Department also had the power and duty to investigate all treatment and disposal facilities, existing and proposed, in order to determine their adequacy. If the Department concluded that they were inadequate, it could order any changes deemed necessary in their location, design, or method of operation.

After an exhaustive two-year investigation into the problems of water pollution by an Assembly interim committee ${ }^{2}$ the legislature in 1949 replaced this system of control with the present law. ${ }^{3}$ For purposes of this discussion, the most important enactments were the Dickey Water Pollution Act, which created the present water pollution control boards and outlined their responsibilities, and certain annendments to the Health and Safety Code, which set forth the new responsibility of the State Department of Public Health and local health officers with respect to waste discharges. ${ }^{\circ}$

Two fundamental changes were made in the law. First, there was a separation of control over the economic effects of waste discharges from control over the effects on public health. Jurisdiction over the economic effects was delegated to the newly-created water pollution control boards, while power to abate actual hazards to the public health was vested in the State Departnent of Public Health and local health officers. Second, authority to pass on the adequacy of facilities was eliminated. Instead, control was limited to end results, with the waste discharger left free to attain the prescribed results in any lawful manner. As a consequence, permits which had been granted by the Department of Public Health under the old law lost their effectiveness as privileges or grants of authority. ${ }^{*}$

A unique feature of the Dickey Act is the type of agencies it established

1 See former $\$ \S 5410-45$ CaL. Healti \& SAFETY Code repealed by Cal. Stat. 1949, c. 1550, p. 2789,81 .

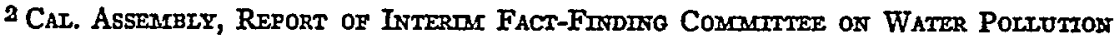
(1949).

8 Cal. Stat. 1949, ce. 1549, 1550, pp. 2782, 2789.

- Car. Water Code $\$ \$ 13000-64$.

- Cal. Heatth \& Safety Code \$\$ 5410-62.

616 Ors. CAL. Atr'y Gen. 29 (1950). 
to administer the act. Primary responsibility is vested in nine regional water pollution control boards. With certain exceptions, each regional board has jurisdiction over one major watershed area of the state. There is no parallel to this regional control system elsewhere in the executive department of our state government. Membership on these regional boards is composed of five men appointed by the Governor for overlapping four-year terms from five specified fields concerned with waste discharge and water quality. Exercising review, supervisory, and coordinating authority over the regional boards is a State Water Pollution Control Board of fourteen nembers. They include representatives of five executive departments of the state government which have a special interest in the subject ${ }^{7}$ and nine members appointed by the Governor, also for overlapping four-year terms. At least one of the appointed members must be chosen from each of seven specified fields concerned with the subject.

The division of functions beween the water pollution control boards and the health agencies is based on the definition of the terms "contamination," "pollution," and "nuisance." "Contamination" is an impairment in the quality of water of the state resulting from the discharge of sewage or industrial waste which causes an actual hazard to the public health. ${ }^{8}$ That there can be no "contamination" unless the public health is in fact endangered is illustrated by an opinion of the California Attorney General that effective exclusion of the public from contact with the larmful water, even though the quality of the water has not been improved, eliminates the contamination. ${ }^{9}$ If a contamination does exist, it is the responsibility of the health agencies to take immediate abatement action for the protection of the public. ${ }^{10}$ Thus, when the health of luman beings is really in jeopardy, emergency action can be taken irrespective of the presence or absence of economic damage from the same waste discliarge.

"Pollution," on the other hand, exists when there are adverse and unreasonable effects on beneficial water uses, falling short of a health menace, resulting from the discharge of sewage or industrial wastes. ${ }^{11}$ The elimination of existing or threatened conditions of pollution is the task of the water pollution control boards. ${ }^{12}$ Contamination and pollution may exist simultaneously with respect to the same water and may be attacked simultaneously by the appropriate pollution board and health agency. ${ }^{13}$

7 CAI. WATER CODE $\$ 13011$ provides, inter alia, that the following state officers or their nominees shall be included in the inembersbip of the state board: The Director of Publlc Health; The State Engineer (now the Director of Water Resources, Cal. Stat. 1957, c. 947); The Director of Natural Resources; the Director of Agriculture; The Director of Fish and Game.

8 Car. Water Code $\$ 13005$; Cad. Heatth \& Safety Code $\$ 5410$ (e).

926 Ors. Car. ATT'y Gen. 253, 256 (1955).

10 Cat. Heatth \& Safety Code $\$ 5412$.

11 Cat. Water Code $\$ 13005$; Cal. Heatth \& Safety Code $\$ 5410(f)$.

12 Cac. Water CODE $\$ 13053$.

1826 Ors. Car. ATT'y Gen. 253 (1955). 
Jurisdiction over "nuisances" is also entrusted to the water pollution control boards. A "nuisance" under these statutes is damage to any commumity by odors or unsightliness resulting from unreasonable practices in the disposal of sewage or industrial waste. ${ }^{14}$ The Attorney General's office has held that the breadth of this defimition does not expand the authority of water pollution control boards to include air pollution resulting from the burning of wastes, or offensive odors or unsightliness resulting from the dumping of dry wastes in areas where waters of the state are not affected. ${ }^{18}$ In other words, only those nuisance effects occasioned by the discharge of wastes into waters of the state or the discharge of water-borne wastes onto dry land are under the control of the water pollution control boards.

Illustrative of the complete elimination of the health agencies from responsibility over the economic consequences of the discharge of wastes is the provision in the law that if the Department of Public Health becomes aware of a condition of pollution or nuisance, its sole duty is to refer the condition to the proper water pollution control board for action. ${ }^{16}$ On the other hand, if the State Water Pollution Control Board finds that a contamination exists and is not being corrected, it has the power to direct that action be taken by any state agency having jurisdiction. ${ }^{17}$

All waters, surface or underground, fresh or saline, within the boundaries of the state are under the protection of these statutes..$^{18}$ The ocean to a distance of three nautical miles out from the outermost islands adjacent to the coast and all bays, harbors, inlets, and estuaries are within the boundaries of the state for this purpose. And all streams, lakes, reservoirs, and ponds within the state, whether publicly or privately owned, are likewise included. ${ }^{18}$

Neither pollution nor nuisance may exist under the law unless the damage is the consequence of the discharge or disposal of sewage or industrial waste. The Attorney General's office has ruled that there can be a waste discharge subject to pollution board regulation if harmful industrial waste currently is draiming into waters of the state, even though the operations which produced the material have long ceased.$^{20}$ Thus, for example, the fact that a mine has been idle for years does not mean that the present seepage of poisonous minerals froin the mine tailings into waters of the state to the damage of beneficial users of the waters may not be a discharge subject to present regulation.

\footnotetext{
14 Cat. Water Code \& 13005; Cat. Health \& SAfEty Code \& 5410(g).

1616 Ops. Cax. AtT'y Gen. 125 (1950).

16 Cat. Heatith \& Safety Code $\$ 5413$.

17 Car. Water Code $\$ 13025$.

18 Id. \& 13005; Cat. Heatth \& Safetr Code \$ 5410(d).

19 Ibid.; CAr. Govr. Code $\$ \S 170-72$.

2026 Ors. Cat. Atr'y Gen. 88 (1955); 27 id. 182 (1956).
} 
The terms "sewage" and "industrial waste" are broadly defined in the law so that they cover practically every kind of waste substance which can result from human activity. "Sewage" means any liquid or solid waste associated with human habitation or containing human or animal excrement, ${ }^{21}$ and has been held to include domestic garbage and rubbish. ${ }^{22}$ "Industrial waste" means any liquid or solid waste, other than sewage, from any producing, manufacturing, or processing operations of whatever nature. Under this definition, the Attorney General's office has ruled that the following materials are industrial wastes: First, earth eroded from areas which have been denuded of protective vegetation by logging operations and exposed to the elements; second, return irrigation or drainage water from agricultural operations if the water contains harmful materials not present prior to the use; and third, liquids containing harmful materials which arise in one stratum intercepted by a water, oil, or gas well and which flow through the well into another intercepted stratum containing water of good quality. ${ }^{23}$ The significant characteristic that each of these has in common with other types of wastes which are unquestionably industrial wastes is that each is an unwanted by-product from a producing, manufacturing, or processing operation. Practically speaking, therefore, each is a waste substance from that operation and those responsible for it should bear the burden of preventing it from unreasonably harming others.

On the other liand, the Attorney General's office has informally advised the water pollution control boards that the intrusion of sea water into coastal underground water basins by reason of over-pumping from those basins does not constitute the discharge of industrial wastes and is thus not subject to correction under the Dickey Act. For in such case, there is no dischage of a waste substance from the pumping operations into waters of the state. ${ }^{24}$

There must, of course, be a causal relationship between the discharge of the sewage or industrial waste and the adverse effect on beneficial water uses or there can be no pollution. That is, the waste discharge must result in an impairment of water quality which in turn ultimately harms a beneficial water use. This causal relationship may exist, however, even if the harm consists of a decrease in the quantity of water available for the beneficial use, as long as the decrease in quantity resulted from the change in quality following the waste discharge. For example, the Attorney General's office recently considered the discharge of a fine-grained industrial waste into water used for replenishment of a ground water basin, presumably for

21 CaL. Water Code $\$ 13005$; CaL. Heatth \& Safetr Code 8 5410 (a).

2227 Ors. Car. Amr'y Grar. 182 (1956).

23 Ibid.

2s Letter from Leonard M. Friedman, Deputy Att'y General, to Warren T. Eannum, Chairman, State Water Pollution Control Board, Nov. 2, 1950. 
later extraction and beneficial use. In the process of percolation of the water, the fine-grained materials settle on and seal the porous surfaces through which the percolation occurs, thereby diminishing or even destroying the capability of these surfaces to absorb water into the underground. The ultimate consequence is that with less water getting into the underground, the quantity of water which can be extracted and used is decreased accordingly. It was held that the necessary causal relationship existed because the change in quality of the receiving water resulting from the waste discharge did have an adverse effect on the beneficial uses to which the water was eventually put. ${ }^{25}$

It has already been pointed out that pollution consists of an adverse and unreasonable effect on beneficial water uses, and that nuisance consists of damage caused by unreasonable practices in waste disposal. ${ }^{26}$ These two elements of adverse effect or damage and of unreasonableness are of central importance in understanding the present law. The mere fact that there is a discharge of waste does not automatically mean that there is a pollution or nuisance.

To a certain extent, water can absorb and dispose of waste materials by dilution and dispersion and natural purification processes without adversely affecting its usefulness for other purposes. Whether harm to a beneficial water use results from the discharge of waste depends upon the facts of each particular case. In many cases even untreated waste can be deposited into a river or body of water without hurting anybody. If that is the case, there is no pollution or nuisance.

But even if there is an adverse effect, that effect must be unreasonable under the particular circumstances in order to constitute pollution or nuisance. ${ }^{27} \mathrm{It}$ is in determining what is or is not reasonable that the water pollution control boards exercise a large part of their discretion. In each specific case, there must be a weighing of the relative economic and social values of the disposal of the wastes against the other beneficial uses of the water affected by such disposal. Waste disposal itself is a beneficial use of water. ${ }^{28}$ As a result, under certain circumstances some impairment of another beneficial use may be deemed reasonable because of its relative unimportance compared to the need to utilize the water for waste disposal.

The process developed by the water pollution control boards to determine reasonableness is the enunciation of the beneficial water uses to be protected. ${ }^{29}$ Since reasonableness is an empirical test and not an absolute

2527 Ors. Car. ArT'Y Gen. 217 (1956).

28 See notes 11 and 14 supra and corresponding text.

2727 Or. CAI. ATr'y GEN. 182, 184 (1956); id. 217, 220.

29 Ibid.

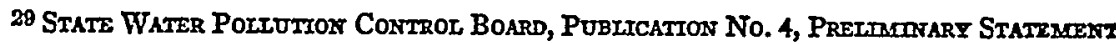

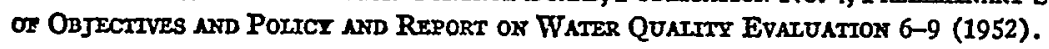


standard, the uses to be protected may change from time to time as the needs and desires of the community change. ${ }^{30}$

As has been stated, the regional water pollution control boards have the primary responsibility to prevent or eliminate pollution and nuisance. This they do by the issuance of what are called waste discharge requirements. These requirements are regulations governing a particular waste discharge, and are designed to protect the beneficial uses of water which the board has decided reasonably should be protected. They are prescribed after such investigation, meetings, or hearings as the regional board believes are necessary. ${ }^{31}$ As contrasted with the permits issued by the State Department of Public Health under the old law, requirements must be stated exclusively in terms of end results which the discharger is to meet. That is, there may be a description either of the required characteristics of the effluent discharged, or the condition of the receiving waters or disposal area which must be maintained after the discharge, or a combination of both. ${ }^{32}$ But, the requirements may not specify the design, location, type of construction, or particular manner in which the waste is to be treated or discharged, nor may they forbid a discharge..$^{33}$ Once the requirements are issued, it is the obligation of the discharger to provide adequate facilities to meet them, and he may do so in any lawful manner without getting approval of his facilities from the regional board. ${ }^{34}$

Any person who is a waste discharger is subject to control. The term "person" is defined as also including "any city, county or district." result, while local public agencies must comply with the requirements of the Dickey Act, this would not seem to cover agencies of the state government as such.

Requirements must be prescribed by each board with respect to every particular condition of pollution or nuisance, existing or threatened, in its region. ${ }^{36}$ In addition, any person proposing to discharge waste must file a report on his proposal with the regional board, and the board must prescribe requirements. Exempted are only those persons making small waste discharges from a family dwelling when the board waives the requirement of a report, or those who discharge into a community sewer system in which event the owner of the system must file the report. ${ }^{37}$

Because pollution or nuisance exists only if unreasonable harm results from a waste discharge, requirements may be no stricter than necessary to

30 CaL. Water Code $\$ 13054$.

31 16 Ops. CaL. AtT'x Gen. 112, 114 (1950); 24 id. 266, 271 (1954).

3216 id. 203 (1950).

83 CaI. Water Code $\S 13064$; 16 Ofs. Car. Atr'y Gen. 200 (1950).

34 CAL. WATER CODE $\$ \$ 13054,13064$.

35 Id. § 13005 .

$36 I d . \S 13053$.

87 Id. 813054 . 
protect the reasonable beneficial uses of the water. Assume, for example, a stream with so great a waste-receiving capacity that the untreated waste of a particular discharger could be accepted without interfering with any beneficial use of the water. In such a case, the regional board could not impose requirements which would compel the discharger to treat the waste. On the other hand, the law carefully preserves the power of the boards to revise the requirements from time to time. ${ }^{38}$ The boards thus can take into account not only changes in technical knowledge and community needs and desires; they can also re-allocate the available waste-receiving capacity of the particular stream among the larger number of municipalities or industries which may have come into the area.

In formulating their requirements, the water pollution control boards can require any state or local agency to inspect and report on the technical factors involved. ${ }^{39}$ This gives them the benefit of the special knowledge and investigative facilities of experts in every field associated with waste disposal and water use, and thus enables them to formulate requirements which will give the best protection obtainable. The boards may also coinpel the discharger responsible for meeting prescribed requirements to monitor the discharge and report the results regularly as a means of determining if the requirements are being complied with. ${ }^{40}$

The issuance of waste discharge requirements is the first step in taking enforcement action against pollution or nuisance under the Dickey Act. If a discharge is occurring contrary to requirements, the board must then hold an administrative hearmg under the California Administrative Procedure Act. ${ }^{11}$ There has been only one such proceeding since the Dickey Act was adopted. If, after a hearing, the board finds that a pollution or nuisance is existing or threatening, it inust order correction. ${ }^{42}$ If the order is disobeyed, the district attorney of the county where the discharge originates or, on his failure to act, the Attorney General must bring an injunction action in the superior court for enforcement of the order. ${ }^{43}$ No such court action has yet been instituted.

In discussing the powers of compulsion delegated to the water pollution control boards, their role in encouraging cooperative, voluntary action should not be ignored. This was regarded as so important by the legislature that the Dickey Act expressly instructs the regional boards to obtain coordinated action in pollution or nuisance control by means of formal or informal meetings, and to encourage and assist in self-policing waste disposal
38 Ibid.
80 Id. $\$ 13052$ (c).
40 Id. § 13055 .
41 Id. $\S \S 13060-61.5$.
42 Id. \$ 13062 .
43 Id. \& 13063. 
programs for industry. ${ }^{44}$ Note should also be taken of the responsibility of each board to formulate and adopt long-range plans and policies with respect to water pollution control within its region. ${ }^{45}$ By sucli plans and policies, the boards can help anticipate and prepare for the problems of the future.

While the regional boards are on the front line of pollution control, the State Water Pollution Control Board also plays an important role. On financial matters it is in a controlling position. It allocates among the regional boards the funds appropriated by the legislature for the support of the water pollution control program; ${ }^{46}$ administers the program of financial assistance to municipalities and districts from the State Water Pollution Control Fund and the grant program of the federal government; ${ }^{47}$ and administers statewide programs of research. ${ }^{48}$

A power of possibly great significance is contained in the provision that the State Board formulate a statewide policy for control of water pollution "with due regard for the authority of the regional boards." ${ }^{40}$ The limits of this authority liave not been explored and the effect of the qualifying words "with due regard for the authority of the regional boards" has not yet been determined.

Regardless of the extent of the authority to formulate statewide policy, the State Board lias a potent instrument of supervision over regional boards. That instrument lies in the State Board's power to review the action of a regional board on any particular existing or threatened condition of pollution or nuisance and, if it finds that the regional board lias failed to act appropriately, either to order the regional board to take corrective action or to take such action itself..$^{50}$ If the State Board decides to act itself, it is vested with all the powers granted to the regional boards concerning the issuance and enforcement of waste discharge requirements. The rules of the State Board governing such review are codified in the California Administrative Code..$^{51}$

This procedure of review lias sonetimes been called an appeal. However, it is not truly an appeal because the review is made on the State Board's own motion. Although the State Board may decide to review and correct the action of a regional board because one of the interested persons requests it to do so, it can act without any outside request. On May 2, 1956,

\footnotetext{
44 Cal. Water Code $\$ 13052$ (a)-52(b).

45 Id. \& $13052(\mathrm{e})$.

46 Id. $\$ 13020$ (f).

47 Id. $\S \S 13023,13100-05$.

48 Id. $\$ 13024$.

40 Id. $\$ 13022$.

60 Id. \& 13025; 24 OPS. CAT. ATT'Y GEN. 266 (1954).

6123 Cat. AdmIn. Code $\$ \$ 2050-55$.
} 
the State Board completed its first and only review since the Dickey Act was passed, in a case involving the discharge of sewage by the City of Los Angeles into Santa Monica Bay. ${ }^{52}$

Although the Dickey Act and the related changes in the Health and Safety Code radically altered state law, they did not supersede all other legal remedies against the harnful effects of waste discharges. The statutes expressly provide that they do not limit the power of a city or county to impose additional restrictions, not in conflict therewith, on the disposal of wastes or to declare, prohibit, and abate nuisances. ${ }^{53}$ The right of any person to maintain any appropriate court action for relief from a private nuisance or from a contamination or pollution is also expressly unaffected. ${ }^{\text {st }}$ And so is the power of any state agency to enforce or administer any provision of law which it is specifically permitted or required to enforce..$^{55}$

One of the provisions of state law administered by other state agencies which is still operative is the prohibition in the Fish and Game Code, enforced by the Department of Fish and Game, against the discharge into the waters of the state of inaterials deleterious to fish life. ${ }^{56}$ However, if the condition of pollution is continuing and chronic, it must be reported to the appropriate regional water pollution control board for correction under the Dickey Act. ${ }^{87}$ There are also restrictions against certain adverse effects on the waters in the Trinity and Klamath River Fish and Game District from waste discharges between July 1 and November 30 each year. ${ }^{58}$

The State Oil and Gas Supervisor still has the responsibility of supervising oil and gas wells to prevent damage to underground and surface water by the infiltration of detrimental substances from those wells. ${ }^{59}$ And in oil and gas leases of state-owned tide and subinerged lands, the State Lands Commission inust include a provision prohibiting the discharge of any waste from the operation into waters of the ocean or any bay or inlet thereof. ${ }^{60}$

\section{II}

\section{ACQUISITION OF THE RIGHT TO USE WATER PREVIOUSLY USED}

Much of the water which is used in California, whether for domestic, municipal, irrigation, or industrial purposes, is discharged or drains back

62 State and Regionat Water Poliution Control Boards Rep. to Governors Councti, MARCH-APREL 1956, pp. $1,5$.

53 Cat. Water Code $\$ 13001$ (a)-O1(b); Cax. Heatrm \& Safety Code $\$ 5415$ (a)-15 (b).

64 CaI. Water Code $\$ 13001$ (d); CaI. Health \& Safety Code $\$ 5415$ (d).

65 Cax. Water Code \$ 13001 (c); Cax. Heatth \& Safety Code \$ 5415 (c).

vo Cax. Fish \& GarIe CODE $§ 5650$.

G7 Id. $\$ 5651$.

E8 Id. $\$ 5800$.

69 CAC. PUB. Res. CODE $\$ \$ 3106,3107$.

${ }^{B 0} I d . \S 6873(\mathrm{~b})$. 
into the natural source from which it was taken or into another natural stream, lake, or underground basin, where it mingles with the water naturally present. If, in this common situation of the use of water and its return to a natural source, the prior user has no plan to re-use the water and interids only to be rid of it, the water is abandoned and becomes part of the public waters of the state, subject to being taken and used in accordance with the general law of water rights. There are two exceptions, however, pertaining to so-called "foreign water," that is, water which has been imported from another watershed or ground water basin.

The first exception is that foreign water may not be taken under riparian right. ${ }^{B 1}$ A riparian right is the right of an owner of land bordering a natural watercourse to use a fair share of the natural flow of such stream for beneficial purposes on his riparian land. This right has long been recognized in California, although niost other western states have repudiated it as inconsistent with the needs of an arid area. The reasoning by which our courts have excluded foreign water froin riparian claim is that such water is present because of artificial augmentation of the stream while a riparian landowner is entitled only to the natural advantages inherent in his land ownership. Appropriation, therefore, is the sole method by which rights to abandoned foreign waters flowing in natural streams may be acquired. ${ }^{02}$ That is, the right is based upon an actual diversion and beneficial use of the water after compliance with the appropriation procedure before the State Water Rights Board prescribed in Division 2 of the Water Code. ${ }^{03}$

The second exception is this: Ordinarily an appropriator of water can object to the mterruption by someone upstream of the flow to which he has a vested right. But, except in unusual circumstances in which the artificial flow has become inherently permanent or has been continued so long as to raise a dedication to the community using it below, the appropriator of foreign water cannot compel continuance of its discharge so that it will be available to him. ${ }^{64}$ The importer nuay discontinue bringing the water in, he may discharge it elsewhere, or he may re-use it under such conditions that it no longer augments the natural supply of the downstream appropriator. This is true even though the importer may have acquired a right as against the downstream appropriator to discharge his waste water into the stream. $^{65}$

61 Bloss v. Rahilly, 16 Cal. 2d 70, 74-76, 104 P.2d 1049, 1050-53 (1940); E. C. Horst \& Co. v. New Blue Point Mining Co., 177 Cal. 631, 171 Pac. 417 (1918).

${ }_{62}$ CAT. WATER Code $\$ \S 1200,1201$, 1202 (d) ; Crane v. Stevinson, 5 Cal. 2d 387, 394, 54 P.2d 1100, 1104 (1936).

63 CAT. WATER CODE $\$ \$ 1000-5008$.

64 Stevens v. Oakdale Irrigation Dist., 13 Cal. 2d 343, 352, 90 P.2d 58, 62 (1939); E. C. Horst Co. v. New Blue Point Mining Co., 177 Cal. 631, 171 Pac. 417 (1918); Wiel, Mingling of Waters, 29 Harv. L. Rev. 137 (1915).

65 Stevens v. Oakdale Irrigation Dist., 13 Cal. 2d 343, 349, 90 P.2d 58, 61 (1939). 
Thus, when water has been abandoned after the first use and has been permitted to drain into a natural stream, lake, or other body of water, the right to reclaim and re-use it is acquired in the same general way as are rights to water which has not been previously used. Appropriation would be the chief method, while use under riparian right could be made if foreign water were not imvolved.

The question which naturally arises at this point is whether one who has a right to make use of water may reclaim and re-use it instead of abandoning it to be recovered by another appropriator.

It is now well established that as part of his original right an appropriator of water may, after using it once, recover it before it leaves his property or his control and re-use it; this is so even though such re-use eliminates the discharge previously made of the water into a natural stream and thus cuts off the flow upon which a downstream appropriator may have relied to the extent of expending large sums of money in constructing facilities to use it. This rule was stated by the California supreme court in 1939 as follows: ${ }^{\text {B6 }}$

'One who, by the expenditure of money and labor, diverts appropriable water from a stream, and thus makes it available for fruitful purposes, is entitled to its exclusive control so long as he is able and willing to apply it to beneficial uses, and such right extends to what is commonly known as wastage from surface run-off and deep percolation, necessarily incident to practical irrigation. Considerations of both public policy and natural justice strongly support such a rule.' (Note 89 A.I.R. 212, quoting from United States v. Haga, 276 Fed. 41 .)

To summarize, one who produces a flow of foreign water for beneficial use and thereafter permits it to drain down a natural stream channel, is ordinarily under no duty to lower claimants to continue importing the supply or to continue maintaining the volune of discharge into the second stream channel at any fixed rate. The rule may liave exceptions, as perhaps where the artificial condition has become inherently permanent and there has been a dedication to the public use, or where the drainage is stopped wantonly to harm a lower party, without other object. But as a general proposition, an irrigation district, after importing water from one river, passing it through irrigation works, and discharging into a natural creek bed in the second watershed, may change the flow of water imported or the volume of water discharged from its works into the second stream, or stop the flow entirely, so long as this is done above the point where the water leaves the works of the district or the boundaries of its land. An exception to the rule is not created by the fact that the district may act upon the water a second time while in its possession, by retaking it at a point of drainage for further beneficial application.

The court's reasoning would seem equally applicable to recovery and re-use of water for domestic, municipal, industrial, or any other beneficial purpose.

${ }^{60} I d$. at $351-52,90 \mathrm{P} .2 \mathrm{~d}$ at $62-63$. 
It was established in the same case that when the original appropriator decides to re-use a flow of water which he has previously used once, he may utilize a natural watercourse to convey the water to the place of re-use, so long as the portion of the channel used is within the boundaries of his property. ${ }^{67}$ Similarly, it has been held that an appropriator of water may, after the water has been put to its first use, utilize a natural underground basin as a storage reservoir and retain a prior right to use the water again, if the basin is in effect the appropriator's reservoir because other water to which he has a right is stored there. ${ }^{e s}$

These cases create what seems to be a new exception to the general rule that once water is allowed to drain into a natural stream or body of water without the intent from the very beginning to recapture it, the water is abandoned and may not be recovered by the first user under his original right. ${ }^{69}$ The exception seems to be that where the water is picked up within the first appropriator's property or area of control, he may use natural facilities to convey or store it for re-use, even if that was not his intent when he began his operations.

On the other hand, it has long been the rule that if it was the appropriator's plan from the outset to use a natural stream channel to convey the water to the place of use, there is no abandonment of the water and the appropriator has the prior right to withdraw the quantity he put in at a point outside his property. ${ }^{70}$ This rule is now codified in the California Water Code. ${ }^{71}$

From these cases, it may be inferred that a city or district which has appropriated water for use by its residents has the right to recover it within its boundaries after it has been once used, treat it if necessary, and distribute it for re-use; and that it may repeat this cycle as often as is practicable. It may do this even though its prior practice was to discharge the once-used water into a natural watercourse or basin from which it has been taken and used by others under appropriative right. If, however, as a practical matter, it is not possible for the city or district to recover the water within its boundaries or before it leaves its facilities, its attempt to do so outside might constitute an interference with another's prior right.

Another principle may also be derived from these cases. The capacity

$6713 \mathrm{Cal} .2 \mathrm{~d}$ at 352,90 P.2d at 63.

68 Los Angeles v. Glendale, 23 Cal.2d 68, 77-78, 142 P.2d 289, 295 (1943).

69 Eddy v. Simpson, 3 Cal. 249 (1853); Wiel, Mingling of Waters, 29 HaRv. L. REv. 137 (1915).

70 Butte Canal and Ditch Co. v. Vaughn, 11 Cal. 143 (1858) ; Hoffiman v. Stone, 7 Cal. 46 (1857).

71 CAL. WATER CODE § 7075 provides: "Water which has been appropriated may be turned into the channel of another stream, mingled with its water, and then reclaimed; but in reclaiming it the water already appropriated by another shall not be diminished." 
of a stream or the ground to treat and purify waste water by natural processes may be used without loss of right to the water in the same way and subject to the same restrictions that the conveyance or storage capability of a stream or underground basin may be used.

But assume a situation in which the original appropriator does not wish to engage in reclamation and re-use of the waste water himself, and instead has a customer who would like to take it off his hands. Does the appropriator have the right to make a charge for the water, and does the customer, by agreeing to take and pay for the water, secure a right to it superior to all others?

A 1950 decision of the California supreme court ${ }^{72}$ seems to accept, without much discussion, the rule that the first appropriator and user of water may, mstead of re-using the water himself, sell it to someone else. Apparently there is no abandonment of the water when it is released to the buyer, and the buyer presumably stands in the seller's shoes as against would-be appropriators of the waste water. This appears to be so even though the seller has no use of his own for the waste water and, absent the sale, would have to abandon it, after which it could be appropriated by others without making any payment to him.

An opinion earlier in 1950 by the district court of appeal in the case of Haun v. De Vaurs ${ }^{73}$ contains a dictum to a similar effect. The decision up held rights of appropriators of foreign waste water as against defendants upstream from them. But the court could not resist commenting on an agreement, which had previously expired, whereby the irrigation district releasing the waste water had sold these defendants the right to use the waste water during a particular irrigation season. The court said: ${ }^{74}$

This agreement did not in any degree affect the appropriative rights of respondents, for those rights were always subject to the right of the district to sell and otherwise dispose of its surplus water before it should have abandoned the same; but the district might abandon its surplus water as it spilled into the slough and if and when it did so the same would, as between the parties hereto, come under the appropriative rights of respondents; or the district might, before such abandonment, make lawful disposition of the same. The appropriative rights of respondents are not infringed by such acts of the district for such rights were at all times subject to the contmgency that the supply of water available for the lower appropriator might be intermittent and might be even terminated entirely at the will of the district.

These cases would seem to indicate that, to the extent an appropriator has the right to recover and re-use water himself, he may transfer the right

72 Stevinson Water Dist. v. Roduner, 36 Cal. 2d 264, 267-71, 223 P.2d 209, 211-13 (1950). 7397 Cal. App. 2d 841, 218 P.2d 996 (1950).

74Id. at 844,218 P.2d at 998. 
to a purchaser. But if there is no willing purchaser, he may not exact a payment for the use by others of water for which he himself has no further need. The practical lesson to be learned is that, although one may be able to secure waste water by appropriating it from a natural source without paying the original appropriator for the privilege, if there is another prospective user who is willing to pay, the water may never be forthcoming.

The discussion above has concerned the right to recover and re-use water which may be owned by the first appropriator of water, his purchaser, or a subsequent appropriator of the waste water after it has been returned to a natural source. Where does the owner and operator of a sewage collection and disposal system, which finds itself in control of large quantities of waste water, fit in?

There does not appear to be any authority directly in point. However, one of two theories may explain the status of such an entity. First, it might be reasoned that by virtue of its accepted function of receiving and conveying away waste water, the sewage system owner has been impliedly granted the right by the appropriator of the water to re-use it or reconvey it to someone else. The second theory, which may be more satisfactory, is that the sewage system owner is in possession of abandoned personal property, that is, waste water in artificial pipes, conduits, and receptacles ${ }^{75}$ over which it has complete dominion until it, in turn, abandons the water. The owner of the system would, therefore, have the right to reclaim and re-use the water itself or to contract to deliver it to others for re-use.

Contracts of this type have in fact been entered into in California. The State Water Pollution Control Board lists as typical examples three public agencies operating sewage treatnent plants which have made such contracts and three others which deliver their sewage effluent to lessees of cityowned land who use it for irrigation. ${ }^{76}$

The only reported court decision which has been found on the legality of contracts selling sewage or sewage effluent is a 1925 Wyoming case, which upheld the power of a city to contract to deliver sewage from the city's sewer line to a ditch serving lands of its purchaser. ${ }^{77}$ The court rejected the argument of a downstream water user that the city was obligated to continue to discharge the sewage into the stream from which the downstream user had been appropriating it, and said that in order to dispose of its sewage without creating a nuisance, the city could confer a superior right to use the sewage upon one who would agree in return to receive it upon his land. ${ }^{78}$ The decision, however, held the contract invalid to the

75 Lewis v. Scazighini, 130 Cal. App. 722, 724, 20 P.2d 359, 360 (1933).

76 State Water Poliution Control Board, Publication No. 12, A Survex of Direct UTIIZATION OF WASTE WATERS 45 (1955).

77 Wyoming Hereford Ranch v. Hammond Packing Co., 33 Wyo. 14, 236 Pac. 764 (1925). 78 Id. at ........, 236 Pac. at 772. 
extent that it attempted to give the purchaser a prior right to take sewage which the city continued to discharge into the stream. That sewage, upon its return to the stream, was held to be part of the public waters of the state subject to appropriation. ${ }^{79}$

Presumably a inajor portion of the waste water which it is contemplated can be reclaimed and re-used in California is received in publicly-owned waste collection and disposal systems. ${ }^{80}$ Whether the agencies owning them have authority to sell the waste water which they collect will therefore affect significantly the amounts which are available to others for re-use. Fortunately it appears that local public agencies presently liave ample powers to do so. Under the Sewer Revenue Bond Law, ${ }^{81}$ any city, county, city and county, and any public or municipal corporation or district which is authorized to acquire, construct, own or operate a sewer system ${ }^{82}$ has the following authority:

(1) To sell or otherwise dispose of the water, sewage effuent, or other byproduct resulting from operation of the system, and to construct, maintain, and operate the works necessary for such purposes. ${ }^{83}$

(2) To construct, maintain, and operate any works necessary to conserve any water or effluent recovered from the system and put it to beneficial use by spreading it for percolation into the underground. ${ }^{84}$

A large variety of districts can own and operate sewer systems and thus have this authority. They include municipal sewer districts, ${ }^{85}$ rural sewer districts, ${ }^{86}$ county sanitation districts, ${ }^{87}$ sewer maintenance districts, ${ }^{88}$ county sewerage and water districts, ${ }^{89}$ joint municipal sewage disposal districts, ${ }^{90}$ regional sewage disposal districts, ${ }^{91}$ sanitary districts, ${ }^{, 2}$ community services districts, ${ }^{93}$ public utility districts, ${ }^{94}$ municipal utility districts, ${ }^{95}$

70 Id. at ........, 236 Pac. at 773.

80 CaItfornia Departarent of Public Works, Division of Water Resources, ReclabsatTON OF WATER FROM SEWAGE OR INDUSTRTAL WASTE 31-38 (1952).

81 CaL. Health \& Safety Code $\$ \S 4950-5063$.

82 Id. \& 4951.

83 Id. $\$ 5008$ (a).

$84 I d . \S 5008(\mathrm{~b})$.

85 Id. $\$ 4606$.

86 Id. $\$ 4664$.

87 Id. $\$ \$ 4741,4744,4745$.

88 Id. $\$ \$ 4870,4885$.

${ }^{89} \mathrm{Id} . \S \S 5541,5544-45$.

80 Id. $\$ 5740.03$.

91 Id. \$ 5995.

82 Id. $\$ 6512$.

93 CaI. Govt. Code $\$ 61600$ (b).

94 CaL. PUb. UT. CODE $\$ 16461$.

95 Id. $\S$ 12801, 12807, 13451. 
and county water districts. ${ }^{96}$ Cities also have express power to lease sewage and sewage effluent for a period not to exceed fifty years. ${ }^{.7}$

The other half of the problem is whether the public water supphers in the state are empowered to reclaim and treat waste water for use by their consumers. As the Legislative Counsel pointed out in an opinion to Assemblyman Randall F. Dickey written in 1950, it seems reasonable to conclude that "agencies which are expressly authorized to obtain and distribute water would have the implied, if not the express, power to give the water any treatment necessary to make it usable for the purposes for which it was distributed. ${ }^{398}$

The legislature has, nevertheless, given some agencies explicit power to reclaim water for beneficial use. For example, irrigation districts may "control, distribute, store, spread, sink, treat, purify, recapture and salvage any water including but not limited to sewage waters for the beneficial use or uses of the district or its inhabitants or the owners of rights to waters therein." ${ }^{\prime 09}$ Virtually identical power is possessed by county water districts ${ }^{100}$ and by mumicipal water districts ${ }^{101}$ and similar power by districts organized under the Water Conservation Act of $1931 .^{102}$

In addition, the flood control and water conservation districts which have been created in a number of counties by similar state statutes typically have power "to conserve and reclaim water for present and future use within the district." ${ }^{\prime 103}$ Among the counties which have such districts are AlaIneda, Contra Costa, Del Norte, Humboldt, Monterey, Napa, Orange, Riverside, San Benito, San Luis Obispo, Santa Clara, and Ventura. ${ }^{104}$

There are, of course, some public agencies which may engage both in waste collection and disposal and in the supplying of water for beneficial use. These agencies may be particularly useful in waste water reclamation because, without the intervention of any other agency, they can acquire a supply of water, distribute it to their consumers, pick it up when it appears as waste water after use, treat it, and then put it back in their water delivery system for re-use, repeating the process as many times as is feasible. Agencies with these powers include cities, ${ }^{105}$ county water districts, ${ }^{100}$ com-

96 Cat. Water Code $\$ 31100$.

97 CAL. Govt. Code $\$ 37390$.

98 Catifornia Departament of Public Works, Diviston of Water Resources, Feasmin ity of the Rechasation aNd Collection of Sewage 50 (1951).

99 CAI. WATER CODE § 22078.

100 Id. $\$ 31047$.

101 CAL. Water Code ANN., act 5243, \& 12 (Deering Supp. 1955).

102 Id., act $9127 \mathrm{c}, \S 20$ (a) (Deering 1954).

${ }^{103}$ E.g., Contra Costa County Flood Control and Water Conservation District Act, id., act $1656, \S 5(5)$.

${ }_{104}$ Id. 3, 55, 186, 386, 456, 476, 619, 694, 753, 800, 899; id., 11 (Deering Supp. 1955).

105 CAI. Govt. CoDE $\$ \$ 38730-42,38900$.

106 CAI. WATER CODE $\S \S 31020,31047,31100$. 
munity services districts, ${ }^{10 \pi}$ public utility districts, ${ }^{108}$ and municipal utility districts. ${ }^{109}$

\section{CONCLUSION}

The law governing quality control and the re-use of water in California is very young. As has been indicated, there are no court decisions whatsoever construing the Dickey Water Pollution $\mathrm{Act}^{110}$ and the companion provisions of the Health and Safety Code relating to water quality control. There are only a few decisions on the acquisition of rights to re-use water. For this reason, the views which have been expressed in this paper are necessarily tentative.

Nevertheless, it is hoped that the information and comments included in this paper will help introduce the busy water lawyer to subjects with which in all likelilood he will be mcreasingly confronted as Califorma strives to satisfy its expanding water needs.

107 Cat. Govt. Code $\$ 61600$ (a)-(b).

108 CAL. PUb. Ut. Code $\$ 16461$.

${ }^{109} I d . \S 12801$.

110 Cat. Water Code $\$ \S 13000-64$. , 